\title{
Comparative Analysis of Electronic Banking Websites in Selected Banks in Poland in 2014
}

\author{
Witold Chmielarz \\ University of Warsaw, Faculty of Management, \\ ul. Szturmowa 1/3, 02-678 Warsaw, Poland \\ Email: witold@chmielarz.eu
}

\author{
Marek Zborowski \\ University of Warsaw, Faculty of Management, \\ ul. Szturmowa 1/3, 02-678 Warsaw, Poland \\ Email: mzborowski@wz.uw.edu.pl
}

\begin{abstract}
The main objective of this article is to identify the best e-banking websites in Poland from the point of view of an individual customer. Using modern IT tools for communications with customers of banking services, banks create competitive advantages, as well as, opportunities for providing banking services in a convenient way for consumers. After a short introduction the authors defines the assumptions for the study. The methodological approach-based on theoretical and empirical study in the field of e-banking, allows them to build the evaluation model for the construction of high quality e-banking website. Subsequently, the authors carried out multilateral analyses and presented the conclusions of the study. The identified categories are classified into three groups: economic, technological and anticrisis. The originality of the work comes down to knowledge of the determinants of customer's quality perception of websites and a starting point for an effective quality management of their e-services system.
\end{abstract}

\section{INTRODUCTION}

I T APPEARS that the consequences of the worldwide crisis in electronic banking in Poland strengthen the tendencies which show that the crisis, which started in the second half of 2008, does not concern this area. Compared to 2013, the number of individual clients with potential access to account increased almost by $15 \%$ (9\% more than in 2012) reaching over 25 million users; the number of active individual clients went up by over 5\% reaching 13.060 million [12]. Undoubtedly it is the fastest growing banking sector andas indicated in earlier articles-nothing points to the fact that something may undermine these positive trends. The increase in absolute numbers of clients is shown in Fig. 1. The increase in the number of clients with potential access to account via the Internet is accompanied by a continuous increase of active customers (at least one transaction a month). Since the end of 2008 till the end of 2014 the number increased by over 13 million users, which is an increase by $123 \%$. Every year the population of new customers using the possibilities offered by the Internet to handle banking transactions is growing. In 2008 more than 890,000 people started to use e-banking services, and in 2014 the number was more than 3 million. There are nearly $53 \%$ of active users, out of all clients having electronic access to account.

Poland in the European statistics-with regard to penetration-compares quite well-according to ComScore [7] report-it takes the sixth place (52.3\%), while the European average is $40 \%$. The largest e-banking

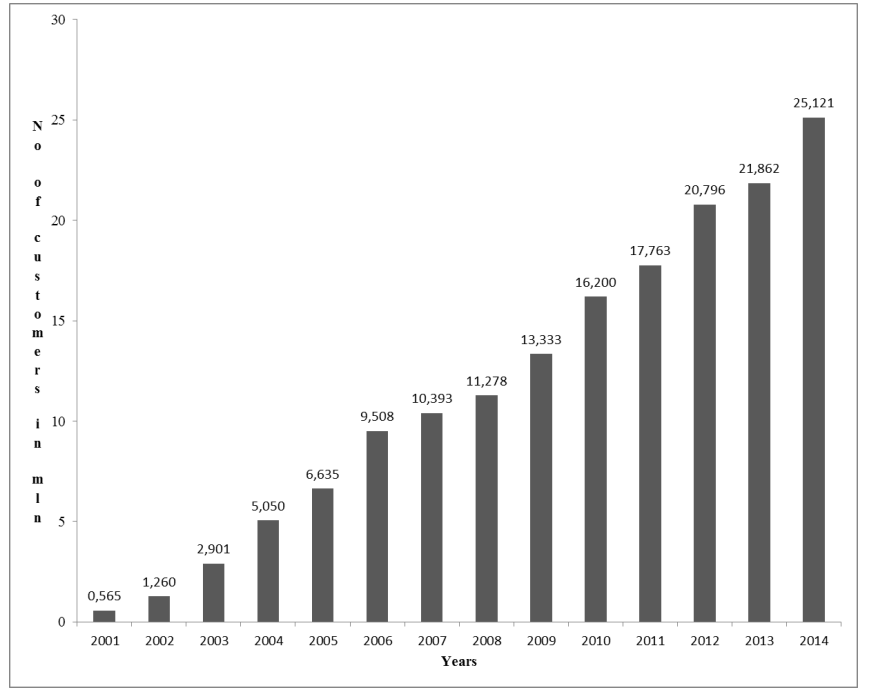

Fig. 1. The evolution of the number of clients with electronic access to account in 2001-2014 in millions [12]

penetration is in the Netherlands-66\%, the lowest in Switzerland (18.8\%). France (60\%), Finland (56.4\%), Sweden $(54.2 \%)$ are ahead of us, behind are among others: Germany, Spain, Denmark and Norway. The dynamics of the increase of the number of e-banking clients in Poland is still one of the highest on our continent-in recent years we note the increase of over one million every year. So, this is very important area of e-services, worth to conduct research.

There are many publications concerning the issue of evaluation of websites [3], [9], [13], [14], [15] and access to ebanking services [1], [10], [11] but there is no easy solution to the problems encountered [12], [6], [16]. The review of the literature shows that e-banking websites (as well as ecommerce websites) may be analysed from the point of view of:

- usability (site map, directory),

- interactivity (availability and responsiveness),

- functionality (search, navigation, relevance of content),

- visualisation (colour scheme, background, graphics, text),

- efficiency (cost of purchase, transport, the difference in prices offered by traditional and online shops), 
- reliability and availability.

Most of evaluation methods are traditional scoring methods based on specific criteria sets, evaluated by means of an applied scale. Technical and functional criteria are the most commonly applied. Most of them contain factors which may be evaluated in a very subjective way: text clarity, attractive colours, images and pictures, the speed and intuitiveness of navigation, etc. Moreover, some users do not treat particular criteria sets in an equivalent way. However, on the other hand, there occur frequent problems with determining preferences for particular criteria and the evaluation of relations between them. This part of the work concerns the application of the authors own, though based on the literature, set of criteria for a scoring evaluation and a selection of electronic services of selected banks.

We are making an comparative analysis mainly in three cases, enabling:

- specification and accurate research into the area in which the software works,

- creating a ranking of IT solutions existing on the market,

- identification of the features which make particular solutions better than others.

Here we are concentrating on the third case.

\section{Assumptions OF THE StUdy}

At the first half of 2014 (March-June), the authors carried out research on the quality of websites offering electronic access to services of the most popular banks among Polish individual clients on a sample of 361 people, where 311 respondents completed surveys correctly. The participants of the survey were students, aged 19-45, Faculty of Management University of Warsaw and Vistula University in Warsaw. Among the respondents, $69 \%$ were women and $31 \%$ men, mainly from Warsaw and surrounding areas. Each of the respondents declared to have at least one electronic access account with one of the banks operating in Poland (fifteenused e-banking services provided by two banks, two peopleof three banks), thus, in total, the authors examined access to 339 active electronic accounts (see Fig. 2).

In the surveyed population majority of people held accounts in the banks which are considered to be internet banks (mBank, Inteligo PKO BP), or regarded as modern (AliorBank, Millenium), or the largest ones (PKO BP, BZ WBK, CityBank). This does not correspond to the numbers of electronic access accounts declared by particular banks, however, considering the facts that only the active accounts were described and the fact that the surveyed population is relatively young and specific, the structure of the use of accounts is probably closer to reality than the one presented on the basis of official statistics.

This study belongs to a series of cyclical, yearly analyses concerning the factors influencing the usability of websites with online access to individual accounts in the banks [4], [5]. The same set of criteria has been applied in the evaluation of e-banking condition at 2013, 2011 and earlier, before the

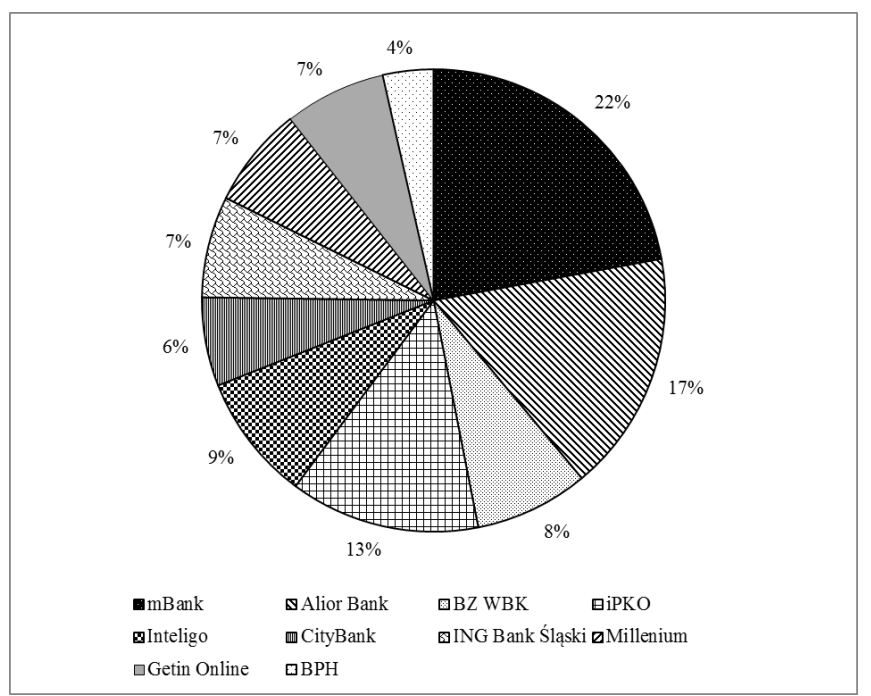

Fig. 2. The percentages of holders of accounts with electronic access in ten the most popular banks

crisis began in 2008. They were created on the base of internet discussion among leading researchers in this field from some universities in Poland (Wrocław University of Economics, University of Economics in Katowice, Poznań University of Economics, University of Szczecin, Faculty of Economic Sciences and Faculty of Management University of Warsaw).

The respondents filled in the tables evaluating e-banking websites of the banks where they had their accounts, performing the analysis and assessment of the obtained results. The tables which they completed were sent by electronic mail. In the second stage, they imposed preference coefficients on particular criteria and performed further calculations. The obtained findings were supplemented with comments. All calculations in the present study are carried out with the application of the authors own, though based on the literature and consultations with experts, set of criteria for a scoring evaluation and a selection of electronic access to services of selected banks.

Criteria applied in this study can be divided into two main groups:

- economic - annual nominal interest rate of personal accounts, account maintenance PLN/month, fee for a transfer to a parent bank, fee for a transfer to another bank, payment order, fee for issuing a debit card, fee for a card PLN/month, interest on savings accounts, interest rate on deposits of 10,000, interest rate on loans 10,000;

- technological-additional services (such as: insurance, investment funds, cross-border transfer or foreign currency account), functionality (set of function available for user), access channels to an account (branches, the Internet, Call Centre, mobile phone), security (ID and password, token, SSL protocol, a list of single-use passwords, a list of single-use codes), visualization (colours, 
fonts, background, photos etc.), navigation, clarity and ease of use.

Considering the situation of the signs of economic crisis spreading, the authors applied a set of psychological criteria in addition to the criteria used previously in the evaluation of e-banking websites which were discussed above. The psychological criteria included the so-called anti-crisis criteria related to-according to the experts cooperating with the authors-all those activities, which were to counteract potential impact of the crisis on the banking sphere [6]. This additional group of criteria was also included in the previous evaluation of e-banking websites. The group of the considered anti-crisis measures includes:

- dynamics of interest rates on deposits (reduction, increase, differences in rates, tendencies),

- dynamics of interest rates on credits (reduction, increase, differences in rates, tendencies),

- stability of the policy related to basic fees (the number and the nature of changes),

- degree of customer confidence (the number of individual clients, its dynamics, how long the bank has been operating in the Polish market),

- the average places occupied in the rankings in the Internet and trade magazines last year.

In the scoring method the authors collected information on selected criteria; they were assigned values according to the assumed scoring scale and the results were analysed in a combined table. For the purposes of the evaluation the authors applied-as in previous studies-a typical R. Likert scale [8]. A scoring method was used in two variations: simple-where criteria were treated equivalently; and one with a preference scale-where sets of criteria were assigned indicator values differentiating their treatment by clients (the total of coefficients $=1$ ).

In a simple scoring method you need to measure the distance from the maximum value to be obtained (according to the assumed scoring scale). It concerns the value of criterion measure and in the sense of a distance it is the same when we measure the distance from one criterion to another as the other way round. However, we do not define the relations between particular criteria. Assigning a preference scale to particular criteria (or sets of criteria) can be regarded as such a measure. A linear preference scale in a normalized form defines in turn the participation of particular criteria in the final score. It establishes a one-time relation between criteria in relation to the final score, it is also a specific "averaged" measure of criteria in particular cases, without the individualization of the evaluation for any of them. However, it does not specify to what degree one criterion is better/ worse than the other. It is merely a derivative of the normalized distance.

\section{Comparative Analysis of Internet ACCESS TO \\ E-BAnKIng ACCOUnts Using a ScORING Method}

To evaluate cost, functional, technological and anti-crisis criteria the authors used a preliminary table presenting bank

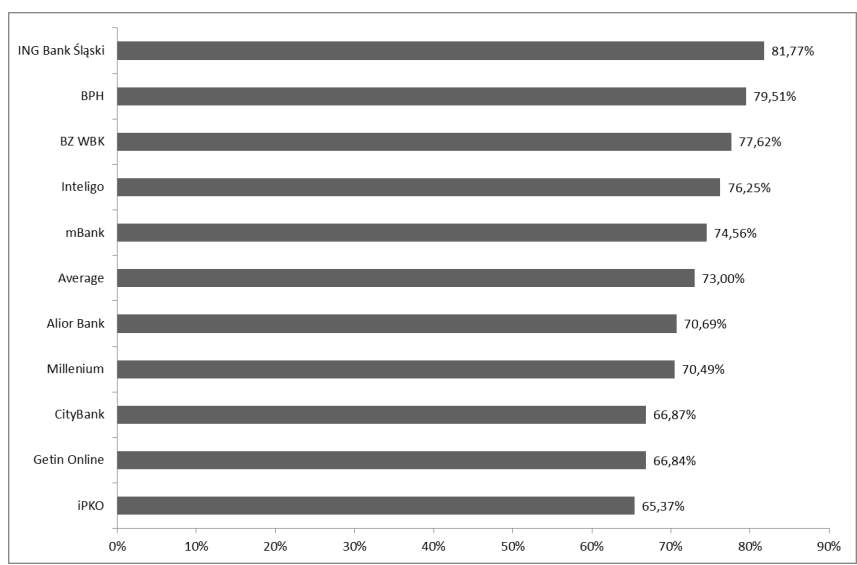

Fig. 3. Ranking of banks for assessing electronic access to individual accounts in selected banks in Poland

offers related to internet banking services used by respondents and fees connected with using bank accounts operated via the Internet. This table has been generated on the basis of data obtained from websites of selected banks. On the basis of the surveys the authors created an averaged combined table for the criteria generated by users.

The spread in the respondents' evaluations of the analysed banks amounts to 16.4 percentage points (compared to 5.1 percentage points in 2011, and 2.3 points in 2008), which reflects the growing diversity of evaluations; which confirms the thesis that the period of crisis increased the radicalism of evaluations and heightened expectations concerning the tools used to access an account.

This time the best in the ranking were: ING Bank Sląski $(81.77 \%)$ and BPH $(79.51 \%)$. Directly behind are: BZ WBK and Inteligo. The low position of mBank (fifth position in the reverse order), came as a surprise because this bank so far occupied leading positions and it was very popular with the analysed group of people (22\% of respondents). It is worth mentioning that in the rankings [17] till May 2011 it held the first position. There occurred a reversal of the situation from three years ago - the banks which two years ago fell in the rankings, at present, are trying to make up for the previous losses. Another issue which seems to be characteristic of this study - general scores for the quality of the websites increased (see Fig. 3.).

In the majority of analysed cases there are no obligatory payments for issuing a debit card; transfers to the parent bank are usually free of charge. The level of security can be regarded as satisfactory for clients. Actually, it has not changed from 2008. Based on the compilation, we can conclude that a fee for issuing a card (usually there is no fee for such a service) reached a level which, at present, may satisfy clients' needs almost in $100 \%$ (96\%). Undoubtedly, the worst indicator is interest rate on savings accounts functionality (evaluated by the majority of users as too low- $37.92 \%$ of the maximum scores). The interest rates on deposits reached over $57 \%$ of maximum score (Fig. 4). From the factors not listed within 


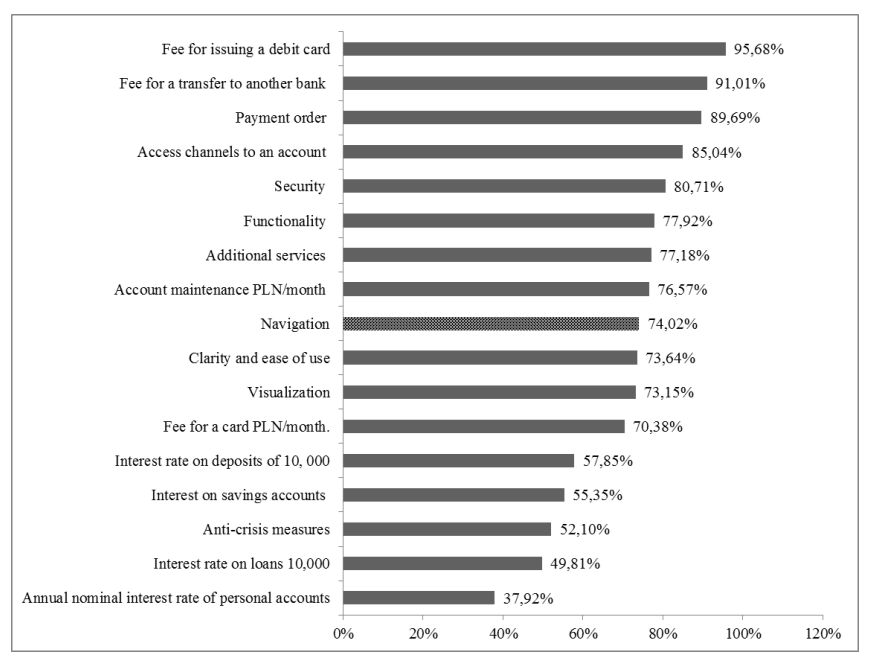

Fig. 4. Ranking of criteria for assessing electronic access to individual accounts in selected banks in Poland in the beginning of 2014

the criteria clients paid attention to the lack of possibility to make a cross-border transfer (e.g. SWIFT in Inteligo) or no possibility of fully automatic obtaining a credit-via the Internet. In 2008 there were no anti-crisis measures among the criteria; however, if we compare this study with the research carried out in 2011, we have to admit that during the crisis ebanking clients neither noticed any signs of the crisis nor were able to define anti-crisis measures undertaken by the banks, and at present they sometimes suggest criteria to be applied for their evaluation.

\section{Comparative Analysis of Internet Access to E-BAnking ACCOUnts by Means of A Scoring Method With PREFERENCES}

One of the methods limiting a specific subjectivity in the experts' or users' evaluations (apart from the previously used averaging of scores) is applying unitary preferences with regard to particular criteria or sets of criteria. For each group the authors applied one dominant variant:

- economic $(70 \%$ for economic criteria and $15 \%$ for the remaining ones),

- technological (70\% for technological criteria and $15 \%$ for the remaining ones),

- anti-crisis (70\% for anti-crisis criteria and $15 \%$ for the remaining ones).

In the first case the three leading positions are taken by ING Bank Śląski, Inteligo and BZ WBK. Next, BPH and mBank are among the best banks with regard to economic factors. iPKO, CitiBank, Alior Bank occupy the last positions of the ten analysed banks. In the leading positions (in the relation to research without preferences) Inteligo moves by two places, Millenium by one place. iPKO BP records the greatest fall.

In the second case the leaders are as follows: BPH, ING Bank Śląski and BZ WBK-further positions are taken by: Inteligo and mBank. The last positions were occupied by: Getin Online, iPKO and Citi Bank.

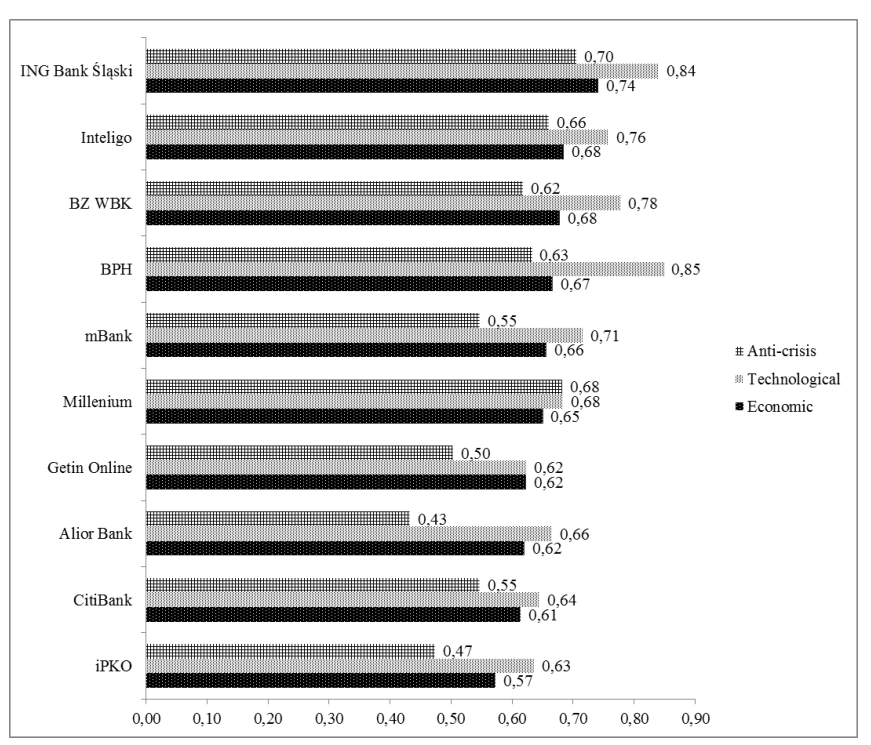

Fig. 5. Ranking of the scores according to various types of preferences for ten selected banks in Poland in the beginning of 2014, according to the order of economic criteria

In the third case the order is very similar to the other evaluations. The first is ING Bank Śląski, next-Millenium and Inteligo. The last positions are occupied by Alior Bank, iPKO and Getin Online.

All in all, multiplaying the values by preference coefficients did not bring about any significant changes in the analysed cases, because the order of the examined websites offering access to e-banking services remained basically the same. The results for the groups are presented in Fig. 5.

\section{Summary And SOME CONCLUSIONS}

The present analysis has shown that the crisis situation, whose signs are visible in various industries, does not apply to electronic banking. While in 2011 it could be a one-off phenomenon, after five years we may conclude that it starts to be seen as a clear trend. Also, it confirms the changes concerning the banking customers' awareness. The choice of the access to an account starts to be a matter of an informed choice, not a chance or habit. The decision is determined both economic and technical conditions. The result is the choices made by clients reflected in the presented study and commented on in the surveys. It is true that some of the opinions indicate-despite the awareness of certain shortcoming of the bank where they hold an account-resistance to changes, but it is the first step to move their account to another bank.

The selection of the research sample and its limitations affected the obtained findings. Students are a group which have relatively the greatest number of access to e-banking and use it most frequently. And know e-banking websites very well. Taking the above factors into consideration, it appears to be the best sample for carrying out the research. This group in the population also has a wide, and perhaps the greatest, knowledge concerning the newest technologies and 
their use. The selection of the student groups was random, the dominance of women and students of early years of study are accidental. However, it is a group which does not have considerable financial resources, and this may be the reason why the representatives of this group have relatively the cheapest access to the internet banking websites. Simultaneously, the awareness of the high usability of information technology means that this particular group is able to appreciate the practical (or entertainment) value of the offered e-banking services. In addition, the representatives of this group, after a few years of using e-banking websites designed for them, are less likely to be satisfied with a product or service-in the form of e-banking website for example-of lower quality.

Taking into consideration the conducted analyses, we may draw the following conclusions:

- in the minds of users of electronic banking a clear distinction between the virtual banks (electronic access only) and electronic access services of traditional banks lost its importance, and it appears to be a continued trend. It is caused by the following phenomena (quotation from a student's survey: ... as we can see the results are comparable. This is due to the large similarity of services offered by banks with regard to visualisation and "starting package", that is all for 0zł ...): virtual and traditional banks try to maximally increase the number of communication channels, it is difficult to separate a virtual bank from a traditional one, e-banking websites of traditional banks are just as technologically advanced and modern as those of virtual banks, we observe lowering of that prices of basic e-banking services in traditional banks, sometimes below the prices of virtual banks, we have a more possibility of access-phenomenon of mobile banking via mobile applications (smartphones, tablets),

- users have higher expectations with regard to the quality of e-services. The averages from the rankingspreviously relatively constant-have become dynamic and fluctuate,

- entering the market (for example-the case of Alior Bank) and allocating significant resources to a clever advertising campaign does not guarantee an automatic promotion to the top position in the rankings (for exampleCredit Agricole),

- having two or more accounts in two or more banks to perform various financial transactions is still a rare phenomenon,

- too few clients dynamically respond to changes in banking services market,

- vast majority of active bank customers consider economic criteria to be the most important criteria in the evaluation of electronic access to banking services-usually the prices of the most frequently used services. More and more people admit, however, that when selecting a website, to a certain degree, they tend to focus on user-friendliness and intuitiveness as well as the visual attractiveness of the website (quotation from a student's survey (original phrasing): ... personally, when selecting banking services, I am more influenced by economic factors than the visualisation or the simplicity or complexity of navigation. Visual qualities depend on a personal taste, and I think they should not be a decisive factor in the selection of a financial institution, to which we entrust our own money. With regard to the technical and functional level of the service, it does not determine my choice-especially since the current market seems to have developed a certain standard, below which banks can no longer operate because customers are bound to verify it quickly and leave ...),

- users of electronic banking services more frequently notice anti-crisis measures of banks and even though they do not influence their choices in any considerable degree, they can note and identify them.

This confirms the authors thesis about the inadequacy and a specific superficiality of standard, unified, quantitative methodologies used for evaluation and selection of e-banking websites. It also points to the need of further studies into constructing multi-dimensional, multi-criteria, hierarchical and multi-faceted system for websites' evaluation, with the consideration of additional, more specific information, e.g. customer profile [3].

Nevertheless, despite the problems related to using ebanking services, which the article presents, from year to year we observe that the Internet tends to assume the role of the main (also for an individual client) channel of communication with the bank. Undoubtedly, this development irrevocably changes the expectations, perceptions and habits related to using banking services which users have had so far, and also, simultaneously, it urges the banks to introduce quick changes of the medium which would take into account holders' requirements.

\section{REFERENCES}

[1] H. Bauer, M. Hammerschmidt, T. Falk, "Measuring the quality of ebanking portals", International Journal of Bank Marketing, vol. 23 no. 2, 2005, pp. 153-175.

[2] W. C. Chiou, C. C. Lin, C. Perng, "A strategic framework for website evaluation based on a review of the literature from 1995-2006", Information \& Management, vol. 47, no. 5-6, 2010, pp. 282-290.

[3] W. Chmielarz, "Koncepcja ekspertowego systemu oceny i selekcji witryn internetowych", chapter 4, Koncepcje zastosowań Systemów ekspertowych [in:] Wiedza i komunikacja w innowacyjnych organizacjach. Systemy ekspertowe-wczoraj, dziÅŕ, jutro, edited by J.Gołuchowski, B. Filipczyk, Prace Naukowe UE w Katowicach, Wydawnictwo UE w Katowicach, Katowice. pp. 183-190.

[4] W. Chmielarz, "Methodological Aspects of the Evaluation of Individual E-Banking Services for Selected Banks in Poland", chapter 11 [in:] Infonomics for Distributed Business and Decision-Making Environments. Creating Information System Ecology, edited by M. Pańkowska, IGI Global, Business Science Reference, Hershey-New York, 2010, pp. 201-216.

[5] W. Chmielarz, "Comparative analysis of electronic banking services in selected banks in Poland in 2013", in: Current Problems of Banking Sector Functioning in Poland and East European Countries, red. Naukowa A. Gospodarowicz, D. Wawrzyniak, nr 316, Prace Naukowe Uniwersytetu Ekonomicznego we Wrocławiu, Wrocław, 2013, pp. 16-29. 
[6] W Chmielarz, "Metody oceny elektronicznych usług bankowych dla klientów indywidualnych w Polsce", [in:] edited by A. Gospodarowicz: Bankowość detaliczna — idee, modele, procesy, Prace Naukowe Uniwersytetu Ekonomicznego we Wrocławiu, nr 54, Wydawnictwo UE we Wrocławiu, Wrocław, chapter 1, pp. 9-26.

[7] http://www.egov.vic.gov.au/focus-on-countries/europe/trends-andissues-europe/statistics-europe/internet-statistics-europe/comscorereleases-2014, Apr. 2014.

[8] R. Likert, "A Technique for the Measurement of Attitudes", [in:] Archives of Psychology, no. 140, 1932, pp. 1-55.

[9] M. B. Mateos, A. C. Mera, F. J. Gonzales, O. R. Lopez, "A new Web assessment index: Spanish universities analysis", [in:] Internet Research: Electronic Application and Policy, no. 11(3), 2001, pp. 226-234

[10] Y.K. Migdadi, "Quantitative Evaluation of the Internet Banking Service Encounter's Quality: Comparative Study between Jordan and the UK Retail Banks", [in:] Journal of Internet Banking and Commerce, no. 2 (13), 2008, pp. 70-79.

[11] F. J. Miranda, R. Cortes, C. Barriuso, "Quantitative Evaluation of e-Banking Web Sites: an Empirical Study of Spanish Banks", [in:] The
Electronic Journal Information Systems Evaluation, no. 2(9), 2004 pp. 73-82, at http://www.eiise.com

[12] NETB@nk-Raport Bankowość internetowa i płatnokści bezgotówkowe. Podsumowanie IV kwartału 2014 r. at: http://www.zbp.pl/Netbank_Q4_2014v3.pdf, April 2015.

[13] M. Sikorski, Usługi on-line. Jakość, interakcje, satysfakcja klienta, Wydawnictwo PJWSTK, 2013, Warszawa.

[14] H. W. Webb, L. A. Webb, "SiteQual: an integrated measure of Web site quality" [in:] Journal of Enterprise Information Management, vol. 17, no. 6,2004 , pp. $430-440$

[15] J. Wielki, "Modele wpływu przestrzeni elektronicznej na organizacje gospodarcze", Wydawnictwo UE we Wrocławiu, Wrocław, 2012.

[16] Z. Yang, S. Cai, Z. Zhou, N. Zhou, "Development and validation of an instrument to measure user perceived service quality of information presenting Web Portals". [in:] Information \& Management, vol. 42, no. 4,2005 , pp. $575-589$.

[17] "Znajdź swój bank", Neewsweek, ranking June/July 2010. SMG/KRC auditors' group, Newsweek, October 3-th 2010, p. 78 